\title{
Alpha beta but not gamma delta T cell clones in synovial fluids of patients with reactive arthritis show active transcription of tumour necrosis factor $\alpha$ and interferon $\gamma$
}

\author{
M Rihl, J Gu, D Baeten, E Märker-Hermann, J C Goodall, J S H Gaston, J G Kuipers, H Zeidler, \\ D T Y Yu
}

\begin{abstract}
Objective: To compare the cytokine expression profile of three CD8+, three CD4+, and three $\gamma \delta+T$ cell clones all derived from the synovial fluids of three patients with reactive arthritis (ReA).

Methods: Complementary DNA based microarrays containing the specific sequence of 56 cytokine transcripts were used for screening. Selected genes were confirmed by reverse transcriptase-polymerase chain reaction assay.

Results: Microarray showed that transcripts encoding for interferon $\gamma$ and tumour necrosis factor $\alpha$ were expressed by all CD8+ and CD4+ T cell clones. However, $\gamma \delta+T$ cells predominantly expressed transforming growth factor $\beta 2$ and granulocyte monocyte-colony stimulating factor.

Conclusion: T lymphocyte clones from the joint of patients with $\operatorname{ReA}$ exhibit differential cytokine expression profiles. CD8+ and CD4+ T cells demonstrate a Th 1 mediated profile, whereas $\gamma \delta+\mathrm{T}$ cells show a more heterogeneous and less proinflammatory Th3 driven pattern.
\end{abstract}

$\mathrm{F}$ om the dramatic therapeutic response to tumour necrosis factor (TNF) blockade in patients with spondyloarthritis (SpA), it can be assumed that TNF $\alpha$ is an immediate and pivotal mediator of the disease process. We have recently used microarray to screen gene expression profiles of synovial fluid mononuclear cells (SFMC), providing evidence for active transcription of mediators, including TNF $\alpha$, interferon $\gamma$ (IFN $\gamma$ ), interleukin (IL) $1 \beta$, IL8, and monocyte chemotactic peptide-1. ${ }^{1}$ Some of these cytokines/chemokines can be generated by both $\mathrm{T}$ lymphocytes and monocytes. So far, we have not distinguished between the two types of cell. This might be important because the effect of anti-TNF $\alpha$ treatment might be directed only against one of them. ${ }^{2}$ Even though the exact role of $\mathrm{T}$ cells in the pathogenesis of reactive arthritis (ReA) remains undetermined, ${ }^{2}$ a body of evidence supports the hypothesis that the disease is induced by an oligoclonal CD8+ $\mathrm{T}$ cell response to a small repertoire of arthritis-causing self peptides presented by the HLA-B27 complex of heavy and light chains. ${ }^{3}{ }^{4}$ As for CD4+ T cells, it has been demonstrated that patients with Chlamydia induced arthritis mount an active CD4+ T lymphocyte response to several discrete chlamydial antigens. ${ }^{5}$ Whether all these ReA related $\mathrm{T}$ lymphocytes generate pro- or anti-inflammatory cytokines has not been examined. Even less clearly defined is the role of $\gamma \delta \mathrm{T}$ cell receptor (TCR) carrying T cells. These cells cannot be ignored because they are also present in the synovial compartment of patients with ReA. ${ }^{6}$

In this descriptive study we examined the cytokine expression of $\mathrm{CD} 8+, \mathrm{CD} 4+$, and $\gamma \delta+\mathrm{T}$ cell clones derived from the synovial fluid of patients with ReA. We used a microarray system containing 56 cytokine related target genes. Our results demonstrate differential cytokine mRNA expression profiles of the three types of T lymphocyte clones.

\section{MATERIAL AND METHODS}

Nine T lymphocyte clones (three CD8+, three CD4+, and three $\gamma \delta+)$ were derived by random cloning from synovial fluid mononuclear cells of three different patients (table 1 ). Patient 1 (three CD8+ clones) presented with acute diarrhoea and arthritis of the left knee and was diagnosed as having enterogenic HLA-B27 associated ReA without identification of the triggering infectious agent. ${ }^{4}$ Patient 2 (three CD4+ clones) had urethritis followed by back pain and arthritis affecting both knees. ${ }^{7}$ Neisseria gonorrhoea was cultured from the urethra; however, the urethritis did not respond to high dose treatment with amoxicillin. Chlamydia cultures were negative but the patient's SFMC showed a much more marked proliferative response to Chlamydia trachomatis than to Neisseriae. Patient 3 (three $\gamma \delta+$ clones) had Yersinia enterocolitica induced ReA, presenting with oligoarthritis and conjunctivitis 2 weeks after an episode of diarrhoea, malaise, and fever. ${ }^{6}$ His SFMC derived clones were reactive to various enterobacteria (Yersinia, Salmonella, E coli). Isolation of the clones has been described in detail. ${ }^{4} 7$

For this study, all clones were randomly selected. They were assayed at baseline and again 2 hours after culture with a stimulatory anti-CD3 monoclonal antibody (Sigma-Aldrich, St Louis, MO). This was performed in order to prove viability and potential responsiveness of the T lymphocyte clones used in this study. In addition, the signalling pathway would be quite similar to activation via the TCR by the HLA-B27peptide complex. It should be noted that it was not the aim of this study to analyse genes induced by CD3 stimulation.

The RNA extraction and microarray procedure followed instructions given by the manufacturers. The method has recently been reported in detail. ${ }^{8}$ We used a filter based nylon membrane containing immobilised cDNA-specific sequences from a total of 1185 genes (Human Atlas Array 1.2, BD Biosciences Clontech, Palo Alto, CA). For analysis, we focused on the 56 cytokines spotted on the membrane, consisting of the majority of characterised interferons, interleukins, tumour necrosis factors, transforming growth factors, bone morphogenetic proteins, and various other

Abbreviations: GM-CSF, granulocyte monocyte-colony stimulating factor; IFN, interferon; IL, interleukin; LT, lymphotoxin; PBMC, peripheral blood mononuclear cells; ReA, reactive arthritis; RT-PCR, reverse transcriptase-polymerase chain reaction; SFMC, synovial fluid mononuclear cell(s); SpA, spondyloarthritis; TCR, T cell receptor; TGF, transforming growth factor; TNF, tumour necrosis factor;

VEGF, vascular endothelial growth factor 
Table 1 Characteristics of nine SFMC derived T cell clones from three patients

\begin{tabular}{|c|c|c|c|c|c|}
\hline $\begin{array}{l}\text { Patient No } \\
\text { (age, sex) }\end{array}$ & Diagnoses & $\begin{array}{l}\text { TCR/ } \\
\text { T cell }\end{array}$ & Clone & Description & Ref \\
\hline $1(46$, male) & Enterogenic HLA-B27 associated $\operatorname{ReA}$ & $\begin{array}{l}\alpha \beta C D 8+ \\
\alpha \beta C D 8+ \\
\alpha \beta C D 8+\end{array}$ & $\begin{array}{l}\text { CD8/1 } \\
\text { CD8/1+ } \\
\text { CD8/2 } \\
\text { CD8/2+ } \\
\text { CD8/3 } \\
\text { CD8/3+ }\end{array}$ & $\begin{array}{l}\text { SFMC derived, TCR in colon, synovium, PB } \\
\text { SFMC derived, TCR in colon, synovium, PB } \\
\text { SFMC derived }\end{array}$ & 4 \\
\hline $2(28$, male) & $\begin{array}{l}\text { Genitourinary Chlamydia trachomatis } \\
\text { induced } \operatorname{Re} A\end{array}$ & $\begin{array}{l}\alpha \beta C D 4+ \\
\alpha \beta C D 4+ \\
\alpha \beta C D 4+\end{array}$ & $\begin{array}{l}\text { CD4/1 } \\
\text { CD4/1+ } \\
\text { CD4/2 } \\
\text { CD4/2+ } \\
\text { CD4/3 } \\
\text { CD4/3+ }\end{array}$ & $\begin{array}{l}\text { SFMC derived, DR4 restricted, specific for chlamydial pmpD } \\
\text { SFMC derived, DR4 restricted, specific for chlamydial omp2 } \\
\text { SFMC derived, DR4 restricted, specific for chlamydial Hsp60 }\end{array}$ & 7 \\
\hline $3(19$, male $)$ & Yersinia induced ReA & $\begin{array}{l}\gamma \delta+ \\
\gamma \delta+ \\
\gamma \delta+\end{array}$ & $\begin{array}{l}\mathrm{gd} / 1 \\
\mathrm{gd} / 1+ \\
\mathrm{gd} / 2 \\
\mathrm{gd} / 2+ \\
\mathrm{gd} / 3 \\
\mathrm{gd} / 3+\end{array}$ & $\begin{array}{l}\text { SFMC derived, enterobacteria reactive (Yersinia, Salmonella, E coli) } \\
\text { SFMC derived, enterobacteria reactive (Yersinia, Salmonella, E coli) } \\
\text { SFMC derived, enterobacteria reactive (Yersinia, Salmonella, E coli) }\end{array}$ & 6 \\
\hline
\end{tabular}

' + ' indicates stimulation with monoclonal anti-CD3 antibody.

SFMC, synovial fluid mononuclear cells; TCR, T cell receptor; PB, peripheral blood; pmpD, polymorphic membrane protein D; omp2, outer membrane protein 2; Hsp, heat shock protein.

growth factors (see http://www.clontech.com/atlas/genelists/ for detailed information; accessed 28 September 2004).

Signal intensity of each gene was measured by a phosphorimager and normalised using the software AtlasImage 1.5 (Clontech). Data from peripheral blood mononuclear cells (PBMC) of six healthy individuals served as control values for $\mathrm{T}$ cell clones. For screening purposes, two criteria had to be satisfied in order to consider a cytokine transcript as being expressed by the array system: $(a)$ the signal intensity of a T cell clone gene had to exceed the mean signal intensity of the same gene from the six normal PBMC by a value which was twofold higher than the average background signals, and $(b)$ the ratio of the signal intensity of the $\mathrm{T}$ cell clone to that of the average of the six normal PBMC had to be greater than two. The criteria for the microarray data analysis were evaluated in a recent publication. ${ }^{8}$

For the CD8+ and CD4+ clones, expression of TNF $\alpha$ and IFN $\gamma$ was measured by a semiquantitative reverse transcriptase-polymerase chain reaction (RT-PCR) assay, which has been reported previously. ${ }^{9}$ Results were considered to be positive when the expression ratio was $>2$ compared with the panel of six normal PBMC. All microarray and RT-PCR measurement values were normalised to the expression level of the glyceraldehyde-3-phosphate dehydrogenase housekeeping gene. Gene-specific sense and antisense RT-PCR primer sequences were obtained from BD Biosciences Clontech. Primer pairs were purchased from Invitrogen/Life Technologies (Carlsbad, CA).

\section{RESULTS}

\section{Microarray assay and verification by RT-PCR}

CD8+ T cell clones

Microarray did not detect TNF $\alpha$ transcripts constitutively, but they were found to be highly expressed after anti-CD3 stimulation, with a mean (SD) ratio of 19.5 (10.1) when compared with six normal PBMC (table 2). For IFN $\gamma$, constitutive expression was detected in clone "CD8/3", and in all clones after culture with anti-CD3. Most remarkably, except for clone "CD8/2", no other cytokine transcripts were detected either constitutively or after anti-CD3 stimulation. For clone "CD8/2", we also detected expression of the following transcripts after anti-CD3 stimulation: IL6, IL13, and placental growth factor. Expression of TNF $\alpha$ and IFN $\gamma$ was verified by RT-PCR in all samples (table 2).

\section{$\mathrm{CD} 4+\mathrm{T}$ cell clones}

Clones "CD4/1" and "CD4/3" expressed TNF $\alpha$ both constitutively and after anti-CD3 stimulation. All three CD4+ clones expressed TNF $\alpha$ after stimulation. For IFN $\gamma$, all clones were positive, in "CD4/3" even constitutively (table 2). CD4+ clones appeared to differ from CD8+ clones in expressing multiple cytokines owing to anti-CD3 stimulation: TNF $\alpha$ and vascular endothelial growth factor (VEGF) C (in both "CD4/ 2 " and "CD4/3"), granulocyte monocyte-colony stimulating factor (GM-CSF; exclusively in "CD4/1"), lymphotoxin (LT) $\alpha$ and IL2 (exclusively in "CD4/2"), and G-CSF, transforming growth factor (TGF) $\beta 1$, and platelet derived growth factor $\mathrm{B}$ (in "CD4/3") (table 2). RT-PCR did not confirm expression of $\mathrm{TNF} \alpha$ in clone "CD4/1" as compared with normal PBMC. However, all other array results of TNF $\alpha$ and IFN $\gamma$ in the CD4+ T lymphocyte clones were confirmed by RT-PCR.

\section{$\gamma \delta+\mathrm{T}$ cell clones}

In these clones, two genes were detected when compared with normal PBMC: TGF $\beta 2$ (ratio 23.4) in clone "gd/l" and GM-CSF in clone "gd/3" (ratio 27.9). Interestingly, these transcripts were expressed only before anti-CD3 stimulation. Activation of the CD3 complex did not cause any induction of cytokines in these particular cell clones. RT-PCR confirmed expression levels of TGF $\beta 2$ and GM-CSF in clones " $\mathrm{gd} / \mathrm{l}$ " and "gd/3".

\section{DISCUSSION}

A large number of papers have been dedicated to the characterisation of CD8+ and CD4+ T lymphocyte clones in patients with SpA. These studies are based on the assumption that $\mathrm{T}$ lymphocytes can directly mediate the arthritis processes. However, the way in which they actually accomplish this has never been examined. A major hypothesis on the pathogenesis of ReA has been proposed by Sieper et al, demonstrating that activated SFMC exhibit a Th2 biased cytokine pattern. Subsequently, persistence of microbial agents in the joints might be due to production of low amounts of IFN $\gamma$ and TNF $\alpha$ as observed by this group. ${ }^{10}$ The same group has also shown that CD4+ synovial fluid cells of 


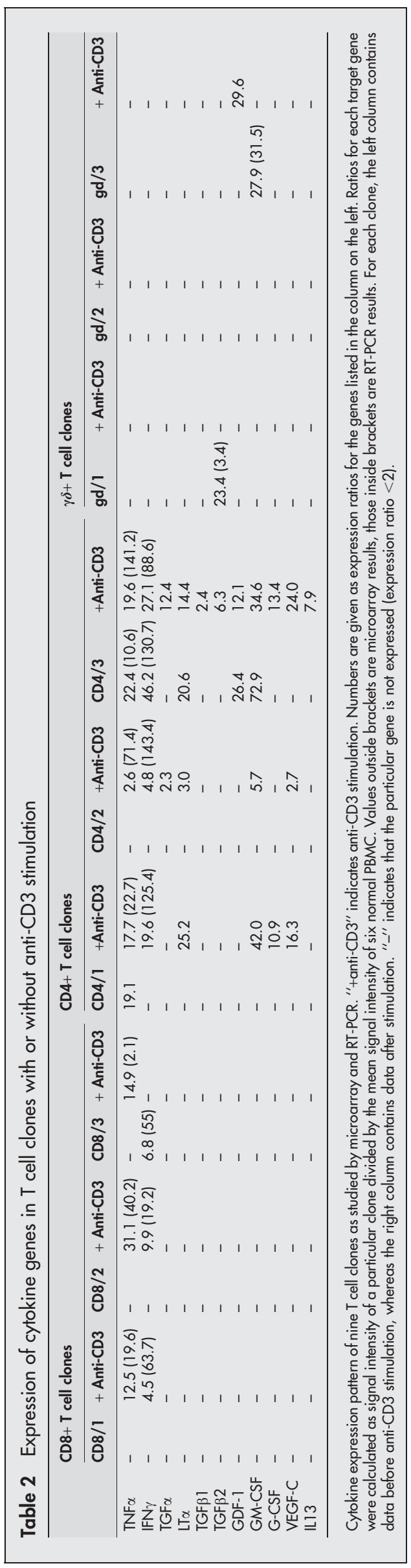

patients with ReA produce lower amounts of IFN $\gamma$ and higher amounts of IL4 than patients with rheumatoid arthritis, suggesting a possible therapeutic role for IL4. ${ }^{11}$ However, another study on synovial tissue samples has shown high amounts of TNF $\alpha$ and IFN $\gamma$ in patients with rheumatoid arthritis and patients with ReA. ${ }^{12}$

Our study examines a potential role of synovial fluid derived $\mathrm{T}$ cell clones in the pathogenesis of ReA by a comprehensive descriptive analysis of such $\mathrm{T}$ cell clones using microarray technology. We demonstrate that both CD8+ and CD4+ cells exhibit a Thl profile showing production of TNF and IFN before and after anti-CD3 stimulation. This might nurture the speculation that $\mathrm{T}$ cells in ReA contribute to pathogenesis by inducing a proinflammatory response rather than by allowing pathogens to persist. On the contrary, $\gamma \delta+\mathrm{T}$ cells appear to have a more heterogeneous cytokine profile, with a potential predominance of Th3 cytokines. This may indicate a different role in the local disease process and possibly even an anti-inflammatory function of these cells. However, it is unclear at present whether the Thl profile as demonstrated here for ReA also extends to other forms of SpA, because most studies describe an impaired Thl response, which predominates in this disease. ${ }^{10} 111314$

One pitfall is the small number of clones that was studied here. However, the selection of these clones was based on the availability of a sufficient number of cells to be used for the microarray assay with no prior knowledge of their cytokine potentials. From that point of view, the results do have a distinct value. Another point of consideration is that the $\mathrm{T}$ lymphocytes were derived from the patients at the height of their arthritis episodes. Conceivably, at the nadir, T lymphocytes would become immunomodulatory instead of being purely proinflammatory. Only a serial analysis would be able to answer this question.

Owing to the limitations described and the lack of functional data, our findings do not allow recommendations in pharmacological usage of TNF blockade in patients with ReA. However, recent and preliminary evidence from two patients suggests that such a treatment strategy may have beneficial effects. ${ }^{15}$

In summary, these comprehensive gene expression analyses imply that $\mathrm{T}$ cells may play a part in joint inflammation by the liberation of Thl cytokines, giving additional insights into the potential pathogenic role of $\mathrm{T}$ cells in ReA which requires further confirmation.

\section{ACKNOWLEDGEMENTS}

This work was supported by the Nora Eccles Treadwell Foundation. The work of $\operatorname{Dr} M$ Rihl was supported by the Deutsche Forschungsgemeinschaft DFG (RI 1119/1-1) and the Rheumatology Competence Network, Berlin. Dr D Baeten is supported by the Fund for Scientific Research-Flanders (FWO-Vlaanderen), Belgium. Dr E Märker-Hermann is supported by DFG, SFB 548 TP B4. Drs JC Goodall and JSH Gaston are supported by the Arthritis Research Campaign UK and the Medical Research Council, UK. Dr JG Kuipers has been supported by research grants from Hannover Medical School (HiLF programme), DFG KU1 182/1-and 1-3; BMBF 01VM9305; BMBF 01 GI 9950, Deutsche Stiftung für Herzforschung; Gesellschaft der Freunde der Medizinischen Hochschule Hannover; BIOMED BMH4-CT-98-3605, and QLRI-CT-2002-02276.

\section{Authors' affiliations}

M Rihl, J G Kuipers, H Zeidler, Hannover Medical School, Department of Rheumatology, Hannover, Germany

M Rihl, J Gu, D T Y Yu, University of California Los Angeles, UCLA School of Medicine, Division of Rheumatology, Los Angeles, CA, USA D Baeten, Ghent University Hospital, Department of Rheumatology, Ghent, Belgium

E Märker-Hermann, Department of Internal Medicine, Dr Horst-Schmidt Hospital, Wiesbaden, Germany 
J C Goodall, J S H Gaston, Department of Medicine, University of Cambridge, Cambridge, UK

Correspondence to: Dr M Rihl, Hannover Medical School (MHH), Department of Rheumatology (OE 6850), Carl-Neuberg-Str 1, 30625 Hannover, Germany; Rihl.Markus@MH-Hannover.de

Accepted 23 February 2004

\section{REFERENCES}

1 Gu J, Rihl M, Märker-Hermann E, Baeten D, Kuipers J, Song YW, et al. Clues to pathogenesis of spondyloarthritis derived from synovial-fluid-mononuclearcell gene expression profiles. J Rheumatol 2002;29:2159-64.

2 May E, Dorris ML, Satumtira N, lqbal I, Rehman MI, Lightfoot E, et al. CD8alpha-beta T cells are not essential to the pathogenesis of arthritis or colitis in HLA-B27 transgenic rats. J Immunol 2003:170:1099-105.

3 Hermann E, Yu DT, Meyer zum Buschenfelde KH, Fleischer B. HLA-B27restricted CD8 T cells derived from synovial fluids of patients with reactive arthritis and ankylosing spondylitis. Lancet 1993;342:646-50.

4 May E, Marker-Hermann E, Wittig BM, Zeitz M, Meyer zum Buschenfelde KH, Duchmann R. Identical T-cell expansions in the colon mucosa and the synovium of a patient with enterogenic spondyloarthropathy. Gastroenterology 2000;1 19:1745-55

5 Matyszak MK, Young JL, Gaston JS. Uptake and processing of Chlamydia trachomatis by human dendritic cells. Eur J Immunol 2002;32:742-51.

6 Hermann E, Ackermann B, Duchmann R, Meyer zum Buschenfelde KH. Synovial fluid MHC-unrestricted gamma delta-T lymphocytes contribute to antibacterial and anti-self cytotoxicity in the spondylarthropathies. Clin Exp Rheumatol 1995;13:187-91.
7 Deane KHO, Jecock RM, Pearce JH, Gaston JSH. Identification and characterization of a DR4-restricted T cell epitope within Chlamydia heat shock protein 60. Clin Exp Immunol 1997; 109:439-45.

8 Rihl M, Baeten D, Seta N, Gu J, De Keyser F, Veys EM, et al. Technical validation of CDNA based microarray as screening technique to identify candidate genes in synovial tissue biopsy specimens from patients with spondyloarthropathy. Ann Rheum Dis 2004;63:498-507.

9 Seta N, Granfors K, Sahly H, Kuipers JG, Song YW, Baeten D, et al. Expression of host defense scavenger receptors in spondylarthropathy. Arthritis Rheum 2001;44:931-9.

10 Yin Z, Braun J, Neure L, Wu P, Liu L, Eggens U, et al. Crucial role of interleukin-10/interleukin-12 balance in the regulation of the type $2 \mathrm{~T}$ helper cytokine response in reactive arthritis. Arthritis Rheum 1997;40:1788-97.

11 Yin Z, Siegert S, Neure L, Grolms M, Liu L, Eggens U, et al. The elevated ratio of interferon gamma-/interleukin-4-positive T cells found in synovial fluid and synovial membrane of rheumatoid arthritis patients can be changed by interleukin- 4 but not by interleukin-10 or transforming growth factor beta. Rheumatology (Oxford) 1999;38:1058-67.

12 Kotake S, Schumacher HR Jr, Yarboro CH, Arayssi TK, Pando JA, Kanik KS, et al. In vivo gene expression of type 1 and type 2 cytokines in synovial tissues from patients in early stages of rheumatoid, reactive, and undifferentiated arthritis. Proc Assoc Am Physicians 1997; 109:286-301.

13 Baeten D, van Damme N, van den Bosch F, Kruithof E, de Vos M, Mielants H, et al. Impaired Th1 cytokine production in spondyloarthropathy is restored by anti-TNFalpha. Ann Rheum Dis 2001;60:750-5.

14 van Damme N, de Vos M, Baeten D, Demetter P, Mielants H, Verbruggen G, et al. Flow cytometric analysis of gut mucosal lymphocytes supports an impaired Th1 cytokine profile in spondyloarthropathy. Ann Rheum Dis 2001;60:495-9.

15 Oili KS, Niinisalo H, Korpilahde T, Virolainen J. Treatment of reactive arthritis with infliximab. Scand J Rheumatol 2003;32:122-4. 